\title{
Front Matter: Volume 9117
}

, "Front Matter: Volume 9117," Proc. SPIE 9117, Three-Dimensional Imaging, Visualization, and Display 2014, 911701 (20 June 2014); doi: $10.1117 / 12.2074010$

SPIE Event: SPIE Sensing Technology + Applications, 2014, Baltimore, MD, United SPIE. States 


\title{
PROCEEDINGS OF SPIE
}

\section{Three-Dimensional Imaging, Visualization, and Display 2014}

\author{
Bahram Javidi \\ Jung-Young Son \\ Osamu Matoba \\ Manuel Martínez-Corral \\ Adrian Stern \\ Editors
}

5-7 May 2014

Baltimore, Maryland, United States

Sponsored and Published by

SPIE 
The papers included in this volume were part of the technical conference cited on the cover and title page. Papers were selected and subject to review by the editors and conference program committee. Some conference presentations may not be available for publication. The papers published in these proceedings reflect the work and thoughts of the authors and are published herein as submitted. The publisher is not responsible for the validity of the information or for any outcomes resulting from reliance thereon.

Please use the following format to cite material from this book:

Author(s), "Title of Paper," in Three-Dimensional Imaging, Visualization, and Display 2014, edited by Bahram Javidi, Jung-Young Son, Osamu Matoba, Manuel Martínez-Corral, Adrian Stern, Proceedings of SPIE Vol. 9117 (SPIE, Bellingham, WA, 2014) Article CID Number.

ISSN: 0277-786X

ISBN: 9781628410549

Published by

SPIE

P.O. Box 10, Bellingham, Washington 98227-0010 USA

Telephone +1 3606763290 (Pacific Time) · Fax +1 3606471445

SPIE.org

Copyright (C) 2014, Society of Photo-Optical Instrumentation Engineers.

Copying of material in this book for internal or personal use, or for the internal or personal use of specific clients, beyond the fair use provisions granted by the U.S. Copyright Law is authorized by SPIE subject to payment of copying fees. The Transactional Reporting Service base fee for this volume is $\$ 18.00$ per article (or portion thereof), which should be paid directly to the Copyright Clearance Center (CCC), 222 Rosewood Drive, Danvers, MA 01923. Payment may also be made electronically through CCC Online at copyright.com. Other copying for republication, resale, advertising or promotion, or any form of systematic or multiple reproduction of any material in this book is prohibited except with permission in writing from the publisher. The CCC fee code is 0277-786X/14/\$18.00.

Printed in the United States of America.

Publication of record for individual papers is online in the SPIE Digital Library.

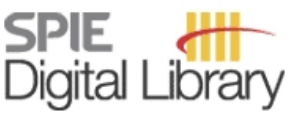

SPIEDigitalLibrary.org

Paper Numbering: Proceedings of SPIE follow an e-First publication model, with papers published first online and then in print and on CD-ROM. Papers are published as they are submitted and meet publication criteria. A unique, consistent, permanent citation identifier (CID) number is assigned to each article at the time of the first publication. Utilization of CIDs allows articles to be fully citable as soon as they are published online, and connects the same identifier to all online, print, and electronic versions of the publication. SPIE uses a six-digit CID article numbering system in which:

- The first four digits correspond to the SPIE volume number.

- The last two digits indicate publication order within the volume using a Base 36 numbering

system employing both numerals and letters. These two-number sets start with 00, 01, 02, 03, 04, $05,06,07,08,09,0 A, 0 B \ldots$. 0Z, followed by 10-1Z, 20-2Z, etc.

The CID Number appears on each page of the manuscript. The complete citation is used on the first page, and an abbreviated version on subsequent pages. Numbers in the index correspond to the last two digits of the six-digit CID Number. 


\section{Contents}

vii Conference Committee

SESSION 1 HOLOGRAPHIC IMAGING TECHNOLOGIES I

911704 Holographic stereogram printing under the non-vibration environment [9117-3]

B. Lee, J.-H. Kim, K. Moon, Electronics and Telecommunications Research Institute (Korea, Republic of); I.-J. Kim, Justek Inc. (Korea, Republic of); J. Kim, Electronics and Telecommunications Research Institute (Korea, Republic of)

911705 Accurate quantitative phase imaging through telecentric digital holographic microscopy [9117-4]

A. Doblas, E. Sánchez-Ortiga, M. Martínez-Corral, G. Saavedra, Univ. de València (Spain);

J. Garcia-Sucerquia, Univ. Nacional de Colombia Sede Medellín (Colombia)

911706 Measurement of depth representation using integral imaging for quality evaluation of computer-generated hologram [9117-5]

S. Lee, J. Nam, E.-Y. Chang, Electronics and Telecommunications Research Institute (Korea, Republic of); S.-K. Lee, Inha Univ. (Korea, Republic of); K. Moon, J. Kim, Electronics and Telecommunications Research Institute (Korea, Republic of)

911707 Generation of three-dimensional color images by a horizontally scanning holographic display (Invited Paper) [9117-6]

Y. Takaki, Tokyo Univ. of Agriculture and Technology (Japan)

911708 Fluctuations in the intensity read out of CCD/CMOS arrays in digital holographic setups: an experimental investigation [9117-7]

Y. Wu, D. P. Kelly, Technische Univ. Ilmenau (Germany); A. Stern, Ben-Gurion Univ. of the

Negev (Israel); S. Sinzinger, Technische Univ. Ilmenau (Germany)

911709 Portable low-coherence interferometry for quantitatively imaging fast dynamics with extended field of view (Invited Paper) [91 17-13]

N. T. Shaked, P. Girshovitz, I. Frenklach, Tel Aviv Univ. (Israel)

\section{SESSION 2 HOLOGRAPHIC IMAGING TECHNOLOGIES II}

$91170 \mathrm{~A}$ Speckle suppression in computational hologram generated using ray-sampling plane (Invited Paper) [9117-8]

M. Yamaguchi, T. Utsugi, Tokyo Institute of Technology (Japan)

9117 OB Acceleration of color computer-generated hologram from three-dimensional scenes with texture and depth information (Invited Paper) [9117-9]

T. Shimobaba, T. Kakue, T. Ito, Chiba Univ. (Japan) 
9117 OC Digital speckle reduction in holograms: a comparison between methods [9117-10] A. Stern, V. Farber, A. Uzan, Y. Rivenson, Ben-Gurion Univ. of the Negev (Israel)

9117 OD Multi-parameter motion-picture recording with wide space-bandwidth by parallel phase-shifting digital holography (Invited Paper) [9117-11]

T. Tahara, Kansai Univ. (Japan); P. Xia, Kyoto Institute of Technology (Japan) and Japan Society for the Promotion of Science (Japan); Y. Awatsuji, K. Nishio, S. Ura, Kyoto Institute of Technology (Japan); T. Kubota, Kubota Holography Lab. Corp. (Japan); O. Matoba, Kobe Univ. (Japan)

\section{SESSION 3 RELATED TECHNOLOGIES OF 3D IMAGING}

9117 OE Liquid crystal lens array for 3D endoscope application (Invited Paper) [9117-12]

A. Hassanfiroozi, T.-H. Jen, Y.-P. Huang, H.-P. D. Shieh, National Chiao Tung Univ. (Taiwan)

9117 OF High dynamic depth range for 3D image capturing system [9117-14]

Y.-P. Huang, P.-Y. Hsieh, Y.-R. Su, H.-P. D. Shieh, National Chiao Tung Univ. (Taiwan)

$9117 \mathrm{OH}$ From the plenoptic camera to the flat integral-imaging display (Invited Paper) [9117-16] M. Martínez-Corral, A. Dorado, H. Navarro, A. Llavador, G. Saavedra, Univ. de València (Spain); B. Javidi, Univ. of Connecticut (United States)

$91170 \mathrm{~J}$ Novel measurement method of multi-view 3D display for determining an optimum viewing distance (OVD) [9117-18]

K.-H. Yoon, Korea Institute of Science and Technology (Korea, Republic of) and Univ. of Seoul (Korea, Republic of); H. Ju, Gachon Univ. (Korea, Republic of); H. W. Kim, S. K. Yoon, Korea Institute of Science and Technology (Korea, Republic of) and Korea Univ. (Korea, Republic of); S.-K. Kim, Korea Institute of Science and Technology (Korea, Republic of)

9117 OK In memoriam: Fumio Okano, innovator of 3D display (Invited Paper) [9117-19] J. Arai, NHK Japan Broadcasting Corp. (Japan)

$9117 \mathrm{OL}$ 3D reconstruction method based on time-division multiplexing using multiple depth cameras [9117-21]

J.-H. Kang, KwangWoon Univ. (Korea, Republic of); D.-S. Lee, Korea Institute of Science and Technology (Korea, Republic of); M.-C. Park, Korea Univ. of Science and Technology (Korea, Republic of) and Korea Institute of Science and Technology (Korea, Republic of); K.-H. Lee, Korea Photonics Technology Institute (Korea, Republic of)

$9117 \mathrm{OM}$ Noninterferometric tomographic reconstruction of 3D static and dynamic phase and amplitude objects (Invited Paper) [9117-22]

S. Memarzadeh, Univ. of Dayton (United States); G. T. Nehmetallah, Catholic Univ. of America (United States); P. P. Banerjee, Univ. of Dayton (United States) 
$911700 \quad$ Interactive holographic display (Invited Paper) [9117-24]

J.-Y. Son, Konyang Univ. (Korea, Republic of); B.-R. Lee, J.-W. Kim, Electronics and Telecommunications Research Institute (Korea, Republic of); ○. O. Chernyshov, Konyang Univ. (Korea, Republic of); M.-C. Park, Korea Institute of Science and Technology (Korea, Republic of)

9117 OP Integral photography capture and electronic holography display (Invited Paper) [9117-25] Y. Ichihashi, K. Yamamoto, National Institute of Information and Communications Technology (Japan)

$91170 Q \quad$ Electronic holography using binary phase modulation (Invited Paper) [9117-26]

O. Matoba, Kobe Univ. (Japan)

9117 OR Three-dimensional holographic display using dense ray sampling and integral imaging [9117-27]

X. Xiao, Univ. of Connecticut (United States); K. Wakunami, National Institute of Information and Communications Technology (Japan); J. Nam, J. Kim, Electronics and

Telecommunications Research Institute (Korea, Republic of); B. Javidi, Univ. of Connecticut (United States)

\section{SESSION 7 3D IMAGES AND DISPLAYS I}

9117 OS Depth perception due to captured horizontal motion natural images (Invited Paper) [9117-28]

S. Yano, M. Suzuki, Shimane Univ. (Japan); M.-C. Park, Korea Institute of Science and Technology (Korea, Republic of)

9117 OT Eyetracked optical see-through head-mounted display as an AAC device (Invited Paper) [9117-29]

H. Hua, X. Hu, Univ. of Arizona (United States); C. Gao, Augmented Vision, Inc. (United States); X. Qin, Univ. of Arizona (United States)

9117 OU Affective SSVEP BCI to effectively control 3D objects by using a prism array-based display [9117-30]

S. Mun, M.-C. Park, Korea Institute of Science and Technology (Korea, Republic of) and Korea Institute of Science and Technology (Korea, Republic of)

9117 OV Full resolution stereoscopic television using flicker-free active beam displacement glasses [9117-31]

S. Shestak, D.-S. Kim, S.-W. Cho, Samsung Electronics Co., Ltd. (Korea, Republic of)

9117 OW Computer simulation of moiré waves in autostereoscopic displays basing on spectral trajectories [9117-32]

V. Saveljev, S.-K. Kim, Korea Institute of Science and Technology (Korea, Republic of) 
$91170 X \quad$ Self-referencing digital holographic microscope for dynamic imaging of living cells (Invited Paper) [9117-33]

A. Anand, V. Chhaniwal, S. Mahajan, V. Trivedi, The Maharaja Sayajirao Univ. of Baroda (India); A. Singh, R. Leitgeb, Medizinische Univ. Wien (Austria); B. Javidi, Univ. of Connecticut (United States)

9117 OY Autostereoscopic 3D display system on the properties of both the expanded depth directional viewing zone and the removed structural crosstalk [9117-34] K.-H. Lee, A. Park, D.-K. Lee, Y.-G. Kim, W. Jang, Y. Park, Korea Photonics Technology Institute (Korea, Republic of)

$91170 Z$ Properties of super-multiview images [9117-35]

B.-R. Lee, J.-C. Park, I.-K. Jeong, Electronics and Telecommunications Research Institute (Korea, Republic of); J.-Y. Son, Konyang Univ. (Korea, Republic of)

POSTER SESSION

911712 Photorealistic image synthesis and camera validation from 2D images [9117-23]

J. C. Santos Ferrer, D. González Chévere, V. Manian, Univ. de Puerto Rico Mayagüez (United States)

911713 Spatial distortion elimination in integral Fourier holography with intermediate projection views generation method [9117-36]

C. Yang, Xidian Univ. (China) and Univ. of Connecticut (United States); X. Xiao, Univ. of Connecticut (United States); X. Wang, Xidian Univ. (China); B. Javidi, Univ. of Connecticut (United States)

911714 Bayesian estimation of depth information in three-dimensional integral imaging [9117-37] X. Xiao, B. Javidi, D. K. Dey, Univ. of Connecticut (United States)

911715 Three-dimensional object recognition via integral imaging and scale invariant feature transform [9117-38]

F. Yi, I. Moon, Chosun Univ. (Korea, Republic of)

911717 Volumetric display containing multiple two-dimensional color motion pictures [91 17-40] R. Hirayama, Chiba Univ. (Japan); A. Shiraki, Kisarazu National College of Technology (Japan); H. Nakayama, T. Kakue, T. Shimobaba, T. Ito, Chiba Univ. (Japan)

911718 Extended viewing-angle holographic display with optical fiber arrays backlight [9117-42] H.-E. Kim, M. Park, M. Moon, J.-W. Kim, Electronics and Telecommunications Research Institute (Korea, Republic of)

911719 High-resolution TFT-LCD for spatial light modulator [9117-43]

J. Lee, Y.-H. Kim, C.-W. Byun, J.-E. Pi, H. Oh, G. Kim, M.-L. Lee, H.-Y. Chu, C.-S. Hwang, Electronics and Telecommunications Research Institute (Korea, Republic of) 
9117 1B Nondestructive analysis of advanced materials nonlinear behavior using digital projection moiré [9117-45]

Y. Pourvais, P. Asgari, Univ. of Zanjan (Iran, Islamic Republic of); A. R. Moradi, Univ. of Zanjan (Iran, Islamic Republic of) and Institute for Advanced Studies in Basic Sciences (Iran, Islamic Republic of); O. Rahmani, Univ. of Zanjan (Iran, Islamic Republic of)

9117 1D Multispectral photon counting integral imaging system for color visualization of photon limited 3D scenes [9117-47]

I. Moon, Chosun Univ. (Korea, Republic of)

9117 IE Radial curve-based classification and localization of features for 3D facial expressions [9117-48]

M. D. Samad, K. M. Iftekharuddin, Old Dominion Univ. (United States)

9117 if Comparative analysis of techniques to pick-up hologram data from real object [9117-49] D.-S. Lee, Korea Institute of Science and Technology (Korea, Republic of); M.-C. Park, Korea Institute of Science and Technology (Korea, Republic of) and Korea Univ. Of Science and Technology (Korea, Republic of); J.-Y. Son, Konyang Univ. (Korea, Republic of); K.-H. Lee, Korea Photonics Technology Institute (Korea, Republic of)

9117 1G Partially occluded object reconstruction using multiple Kinect sensors [9117-50] T. Nasrin, F. Yi, S. Das, I. Moon, Chosun Univ. (Korea, Republic of)

Author Index 
Proc. of SPIE Vol. 9117 911701-8

Downloaded From: https://www.spiedigitallibrary.org/conference-proceedings-of-spie on 26 Apr 2023 Terms of Use: https://www.spiedigitallibrary.org/terms-of-use 


\section{Conference Committee}

Symposium Chair

David A. Whelan, Boeing Defense, Space, and Security

(United States)

Symposium Co-chair

Wolfgang Schade, Technische Universität Clausthal (Germany) and Fraunhofer Heinrich-Hertz-Institut (Germany)

Conference Chairs

Bahram Javidi, University of Connecticut (United States)

Jung-Young Son, Konyang University (Korea, Republic of)

Conference Co-chairs

Osamu Matoba, Kobe University (Japan)

Manuel Martínez-Corral, Universitat de València (Spain)

Adrian Stern, Ben-Gurion University of the Negev (Israel)

Conference Program Committee

Arun Anand, Maharaja Sayajirao University of Baroda (India)

V. Michael Bove Jr., MIT Media Laboratory (United States)

Michael T. Eismann, Air Force Research Laboratory (United States)

Pietro Ferraro, Istituto Nazionale di Ottica (Italy)

Toshiaki Fujii, Nagoya University (Japan)

Hong Hua, College of Optical Sciences, The University of Arizona (United States)

Yi-Pai Huang, National Chiao Tung University (Taiwan)

Naomi Inove, National Institute of Information and Communications Technology (Japan)

Dae-Sik Kim, SAMSUNG Electronics Company, Ltd.

(Korea, Republic of)

Jinwoong Kim, Electronics and Telecommunications Research Institute (Korea, Republic of)

Thomas J. Naughton, National University of Ireland, Maynooth (Ireland)

Fumio Okano, NHK Engineering Services, Inc. (Japan)

Wolfgang Osten, Universität Stuttgart (Germany)

Min-Chul Park, Korea Institute of Science and Technology

(Korea, Republic of) 
Sumio Yano, NHK Science \& Technical Research Laboratories (Japan)

Zeev Zalevsky, Bar-llan University (Israel)

\section{Session Chairs}

1 Holographic Imaging Technologies I

Jung-Young Son, Konyang University (Korea, Republic of)

2 Holographic Imaging Technologies II

Adrian Stern, Ben-Gurion University of the Negev (Israel)

3 Related Technologies of 3D Imaging

Bahram Javidi, University of Connecticut (United States)

4 3D Displays

Manuel Martínez-Corral, Universitat de València (Spain)

53 D Imaging and Display

Manuel Martínez-Corral, Universitat de València (Spain)

6 Holographic Displays

Osamu Matoba, Kobe University (Japan)

$7 \quad 3 \mathrm{D}$ Images and Displays I

Hong Hua, College of Optical Sciences, The University of Arizona (United States)

8 3D Images and Displays II

Yasuhiro Takaki, Tokyo University of Agriculture and Technology (Japan) 